\title{
High School Teachers' Representations of Inclusion in Québec
}

\author{
Philippe Tremblay \\ Université Laval \\ Faculté des sciences de l'éducation \\ Département d'études sur l'enseignement et l'apprentissage \\ Québec, Canada
}

\begin{abstract}
The representations of high school language, science, and mathematics teachers in Québec were examined with respect to the Politique québécoise de l'adaptation scolaire which favors the inclusion of special needs students. A questionnaire was administered to 240 Québec high school teachers in either regular or special education classes. This questionnaire asked teachers about the policy's objectives, resources, population, actions and effects. The model for individualized learning classes was also considered (special classes in regular schools). The results show that the teachers were generally highly critical of this new education policy, which was not well received. For example, the majority of teachers believed that they received too many resources to the detriment of their other students. A strong majority of the teachers were in favor of limiting the number of special needs students per regular class. However, significant differences were observed between the regular and special education teachers in terms of their responses.
\end{abstract}

\section{Introduction}

Teachers' social representations play an important role in the success or failure of implemented reforms related to inclusion and its sustainability [1] [2] [3] [4]. Therefore, it is important to understand teachers' representations and attitudes toward the inclusion of students with specific needs to ensure proper implementation.

For over ten years, the new Politique québécoise de l'adaptation scolaire (1999-2000) promotes the inclusion of students with special needs. The goal of this reform was essentially to place the school "at the service of the students based on an assessment of their individual needs by ensuring that this take place in the most natural setting possible for them, as close as possible to their place of residence, with emphasis on their integration within the regular classroom" [5]. Within this framework, the representations of high school language, mathematics, and science teachers and their view of the inclusion of students with behavior disorders, learning disabilities or mild intellectual disabilities (EBD/MID/LD) in the regular school system have been analyzed.

Today, close to $18 \%$ of Québec public school students have special needs and $2 / 3$ are integrated into regular classes in primary education classes compared with about $50 \%$ in secondary school classes [1]. In addition to inclusion, the Politique de l'adaptation scolaire puts forward a non- categorical stance for students with behavior disorders, mild intellectual disabilities or learning disabilities (EBD/MID/LD) in the regular school system. For this student population referred to as "special needs students", no diagnosis is required. The decision to provide special services ultimately lies in the hands of the school principal, following consultation with and assessment by a resource teacher to determine the need for an individual education plan (IEP) for specific intervention.

In the first three years of high school, other than the regular classroom are part-time or full-time in Individualized learning classes (special education classrooms in regular school) for students with EBD/MID/LD. At the end of these three years, these students are generally referred to vocational education. Therefore, although inclusive education was used, schooling in special classes is possible for students with EBD/MID/LD under certain conditions. "The school board must ensure harmonious integration within a class or a regular group of any students whose individual capacity evaluations and needs show that such an integration will facilitate learning and social insertion. It is only when integration constitutes an excessive strain for the school board or that it significantly undermines the rights of other students, that a school board can choose another option than integration in a class or a regular group." [5].

In 2006, the Québec Ministry of Education called for an evaluation of its special education policy. The ensuing Rapport d'évaluation de la politique québécoise de l'adaptation scolaire contained, however, few elements on the level of 
satisfaction or representations of the teachers, in terms of their support needs [6]. The teachers were shown to be moderately satisfied with the response to their need for support, with one in ten unsatisfied and close to a third highly or totally satisfied. The general average level of satisfaction was 2.51/4 for high school teachers and 2.62/4 for special education teachers, with no statistically significant difference between these two averages. Implementation of the reform was thus viewed as moderately conclusive by the authors of the report who emphasized a need for further support and training. Indeed, since the introduction of this reform, a notable decrease has been observed in terms of the participation of high school teachers in related training activities. The report also recommended an increased focus on the individual intervention plan (IIP) and a closer evaluation of school board services.

In 2013, while Cardin, Falardeau and Bidjang analyzed the Quebec teachers' representations in relation to the reform and students with EBD/MID/LD, they observed that the issue of integrating students with difficulties involves the organizing of teachers' workloads [7]. Because of the presence of students with difficulties in the classroom since the reform, teachers state that they devote more time to course preparation for the students with learning difficulties than for those with behavior problems. The teachers contend that, moreover, they must set aside certain program goals in order to focus on upgrading these students, without the help of resource teachers to ensure this integration and the teachers themselves not having the necessary training. This quite negative feedback on teachers integrating students with EBD/MID/LD is felt in the consequences, also negative, that they see. Three-quarters of the teachers claim that this integration has attracted strong students to the private school sector, or more toward the international education programs of the public school system. They also disagree with the idea that integration allows strong students to improve; it would have even had a negative impact on their eagerness to work. Two-thirds of these teachers also believe that integration does not allow weak students to improve themselves. On this point again, teachers clearly express that the reform has few positive effects on the students' ability to learn, whether their ability is strong or weak. In summary, the situation for students with EBD/MID/LD - and even for the stronger students - has manifestly seen little progress, according to the respondents.

\section{Review of the literature}

As mentioned, teachers' representations play a fundamental role in the implementation and sustainability of inclusive education. These representations vary, however, depending on the type of teacher. Studies have shown that high school teachers appear to be less favorable to inclusion than are their peers in primary education and specifically those teaching the basic subjects such as languages, math, and science [3] [8].

In contrast, teachers who have been trained or have experience in special education are more favorable toward students with specific needs [9]. These special education teachers are more optimistic with regard to the possible gains achieved in the regular classroom [10]. The institutional structure of secondary school teaching can partially explain teachers' attitudes. As well, the training received, the subject taught, and experience in school inclusion have equally influenced their representations, as well as the presence of more male teachers (less open to inclusion compared to their female colleagues) and training on the subject being taught [1] [8].

High school teachers doubt their abilities to respond to the needs of the whole class and fear that inclusion affects the class environment, the teaching and the quality of learning [9]. They claim to not have the necessary training to intervene with students with individualized needs, with a large number of these teachers not trained in special education [11]. They also feel there is too much material to teach to have time to look after each student's individual needs [8]. Finally, the teachers express the same needs as their primary-level colleagues, be it a need for training, for support or for time [8] [9] [12].

These teachers believe that not all special needs students can succeed in inclusion and also argue that the presence of these students may negatively impact the other learners in the classroom [12]. The attitudes of the teachers appear to be strongly influenced by both the nature (i.e. behavior problems) and gravity of the students' disabilities (student-related variables) and less so by teacher-related variables. Behaviorally-challenged students receive the most negative reports in the inclusion model. Moreover, variables related to academic environment, such as the availability of material and human resources, have been systematically associated with positive attitudes with regard to inclusive education [4].

\section{Objectives}

In light of these previous studies on high school teachers' negative representations of inclusive education, this study seeks to examine teacher social representations with regard to Québec's new policy on inclusion and students with special needs; specifically, students with emotional and behavioral disorders, mild intellectual disabilities or students with learning 
disabilities (EBD/MID/LD) in secondary education. The goal was also to analyze the differences between teachers in the regular education setting and those in special education (individualized learning classrooms).

\section{Methodology}

French and English language teachers as well as science and mathematics teachers were asked to complete a six-section questionnaire focusing on components of a model (population, objectives, resources, actions, effects, space/time) [13] [14]. Individualized learning classes were also the focus of specific questions. These are the six components taken into consideration in setting out the 57 statements in the questionnaire. The questionnaire was validated using the method developed by Blais and Durand [15] [16].

A total of 246 high school language, math, and science teachers from the province of Québec participated in the study. For evaluation purposes, the participants were divided into three groups: regular $(\mathrm{N}=118)$, special education $(\mathrm{N}=106)$, and mixed (who worked in both types of classes) $(\mathrm{N}=22)$.

The teachers had to take a position in relation to the different statements on a Likert scale (1- completely disagree; 2- somewhat disagree; 3- somewhat agree; 4- completely agree). The median is 2.5 .

Data were analyzed by means of SPSS, with a level of statistical signification of 0.05 . Comparative analyses were also performed (ANOVA), as well as between-group analyses (Bonferroni test) and correlation analyses between items on the questionnaire (Pearson test).

\section{Results}

The results are presented according to the components examined: objectives, resources, population, actions, effects, space/time). The statements concerning the individualized teaching classes have, for their part, been the object of a specific section.

\subsection{The Policy's Objectives}

The findings show that the teachers were generally critical of this inclusion reform, as confirmed by the amount of disagreement. Consequently, in the three groups under study (regular, special education, mixed), the teachers disagreed more on average with the idea of inclusive education for the targeted population: The regular classroom is the best way to educate, socialize, and qualify special needs students $(\mathrm{N}=242 ; \mathrm{M}=2.25 ; \mathrm{SD}=0.79)$.

As well, the teachers disagreed somewhat more with the affirmation Québec's special education policy meets the needs of students with behavior and learning difficulties $(E B D / L D)(\mathrm{N}=$ 247; $\mathrm{M}=2.32 ; \mathrm{SD}=0.72$ ), with no significant difference observed between the three groups of teachers (regular, special education, and mixed).

This latter statement correlated significantly (XXX) with another item, Québec's special education policy favors the academic achievement of EBD/MID/LD students $(\mathrm{N}=241)$, with a very close average $(\mathrm{M}=2.35 ; \mathrm{SD}=$ $0.70)$. The teachers thus had very mixed feelings regarding this reform.

\subsection{Resources}

On this aspect, the teachers indicated that there lacked sufficient resources to effectively support EBD/MID/LD students. Indeed, the response of all three groups of teachers was strongly negative to the affirmation We have sufficient resources to provide quality education for EBD/MID/LD students $(\mathrm{N}=$ $245 ; 1.68 ; \mathrm{SD}=0.63$ ). In contrast, however, the teachers mostly disagreed with the statement There are too many resources for EBD/MID/LD students to the detriment of the other students $(\mathrm{N}=244 ; \mathrm{M}=1.91 ; \mathrm{SD}=0.79)$. Furthermore, differences were observed between the regular education teachers and those in the other two groups, as there were more teachers in this group who believed that too many resources were provided for these students. Lastly, the teachers also claim to disagree more with the statement, "There are enough resources, but they are not well utilized" $(\mathrm{N}=245 ; \mathrm{M}=2.21$; $\mathrm{SD}$ $=.82$ ). There were no differences observed between the three groups of teachers.

Satisfaction in relation to material and human resources is quite mixed. For the statement, "I am satisfied with the quality and quantity of human resources in working with the EBD/MID/LD students in my school" $(\mathrm{N}=$ 243; $\mathrm{M}=2.20 ; \mathrm{SD}=$

.80), the teachers are rather more in disagreement. This is also the case with: "I am satisfied with the quality and quantity of material resources in my school" $(\mathrm{N}=245$; $\mathrm{M}$ $=2.25 ; \mathrm{SD}=.72)$. These two statements are correlated $(\mathrm{r}=.368 ; \mathrm{p}<.001)-$ there are no differences.

\subsection{Population}

On the item EBD/MID/LD students can succeed just as well as the other students in the regular classroom, the teachers expressed doubt that these students could succeed in the regular classroom. $(\mathrm{N}$

$=240 ; \mathrm{M}=2.19 ; \mathrm{SD}=0.77)$. There was also a strong consensus on restraining the number of EBD/MID/LD students per class: The number of 
EBD/MID/LD students per class should be limited $(\mathrm{N}=246 ; \mathrm{M}=3.72 ; \mathrm{SD}=0.56)$. No statistical difference was observed between the three groups of teachers.

A similar response was observed for the affirmation Some EBD/MID/LD students are just too difficult to educate in regular classes, as all three groups strongly agreed with this statement $(\mathrm{N}=246 ; \mathrm{M}=3.58 ; \mathrm{SD}=0.60)$. This item correlated weakly $(\mathrm{r}$

$=-.13 ; \mathrm{p}<.05)$. This item correlated with the item EBD/MID/LD students can succeed just as well as the other students in the regular classroom $(\mathrm{N}=240 ; \mathrm{M}=2.19 ; \mathrm{SD}=0.77)$, which confirms their less than favorable opinion of EBD/MID/LD students in this setting. There are no differences between the three groups of teachers for these two statements.

The teachers in this study were almost unanimous in their representation that these students were slower to learn: $E B D / M I D / L D$ students take more time to perform the required tasks $(\mathrm{N}=241 ; \mathrm{M}=3.89 ; \mathrm{SD}=$ $0.59)$. There are no differences between the three groups of teachers.

\subsection{Actions}

Concerning the actions taken by teachers in promoting their students' school success, strong consensus is generally observed among the teachers. They show, by their responses, that they are very active in the success of these students.

Thus, for the statement "I work closely with the parents to foster the student's success" ( $\mathrm{N}=$ 254; M

$=3,31 ; \mathrm{SD}=.66)$, the teachers strongly agree. And also for the statement: "I actively collaborate with the various contributors at my school to foster the success of all my students" $(\mathrm{N}=254 ; \mathrm{M}=3.59 ; \mathrm{SD}=$

$.55)$. These two statements are correlated $(r=.58$; $\mathrm{p}$

$<.001)$. The differentiation appears to also be a largely utilized approach, according to teachers. "I differentiate my teaching as much as possible for the EBD/MID/LD students in my class". ( $\mathrm{N}=$ 254; $\mathrm{M}=3.16 ; \mathrm{SD}=.73$ ). No other significant difference is observed between the three groups of teachers. This statement correlates with the two preceding ones $(\mathrm{r}=$

$.45 ; \mathrm{p}<.001$ and $\mathrm{r}=.50 ; \mathrm{p}<.001)$.

The teachers agree somewhat more with the statement, "At my school, I get support from remedial or resource teachers to effectively intervene with certain students" ( $\mathrm{N}=247$; $\mathrm{M}=$ 2.66; $\mathrm{SD}=1.02)$. Significant differences are observed between the three teacher groups; while special education teachers are divided on the issue, the regular teachers are strongly in agreement with this statement. There is also a great variability in the responses.

Finally, the intervention plan, a required tool in coordinating actions (interventions) of each group with a student, garners a certain level of adherence from the teachers. Indeed, the teachers are, overall, in favor of this tool: "The intervention plan is an effective tool in fostering the success of these EBD/MID/LD students" $(\mathrm{N}=244 ; \mathrm{M}=2.81 ; \mathrm{SD}=$

$.801)$. There are no differences observed between the three groups of teachers.

\subsection{Effects}

The presence of these students in the regular classroom appeared to generate opposite points of view. First, on the item Being around regular students provides EBD/MID/LD students with positive social models $(\mathrm{N}=235)$, on average, the teachers generally agreed, although the response of the regular education teachers was significantly less favorable than was that of their colleagues in special education ( $\mathrm{M}=$ 2.84; $\mathrm{SD}=0.63)$. Second, on the item: The presence of $E B D / M I D / L D$ students in the regular classroom elicits a negative response from the other students, the teachers were divided $(\mathrm{N}=$ $241 ; \quad \mathrm{M}=2.49 / 4 ; \mathrm{SD}=0.68)$. Differences between teachers were observed, as the special educators agreed more with the affirmation compared to their colleagues in the regular and mixed groups.

A consensus, among the teachers, in this study was that this meant more work. The presence of EBD/MID/LD students appears to have an impact on the teachers' workload. The presence of EBD/MID/LD students in my class calls for extra work on my part in terms of planning $(\mathrm{N}=249 ; \mathrm{M}=3.05 ; \mathrm{SD}=0.77)$. This increase was less significant than for work related to grading: The presence of EBD/MID/LD students in my class requires that I spend more time grading $(\mathrm{N}=243 ; \mathrm{M}=2.56$; $\mathrm{SD}=0.91)$. These two final affirmations were strongly correlated $(\mathrm{r}=.53 ; \mathrm{p}<.001)$ with no differences between the groups of teachers.

Finally, the teachers are divided but more in disagreement concerning the impact inclusion has on school choices for parents: "The presence of EBD/MID/LD students influences the departure of students for private learning establishments or to specialized programs or concentrations" $(\mathrm{N}=239 ; \mathrm{M}$

$=2.41 ; \mathrm{SD}=.94)$. There are no differences observed according to the categories of teachers.

\subsection{Individualized learning classes}

Many differences were observed between the regular education teachers and their colleagues in the special individualized learning classes. On the item Individualized learning 
classes are "for the lost causes" $(\mathrm{N}=246)$, the average was $2.17(\mathrm{SD}=0.82)$, which indicates that the teachers mostly disagreed with the statement. Statistical differences were however observed, with the regular education teachers expressing a higher level of disagreement compared to their peers in special education.

The same response was obtained for the item Individualized learning classes are the best way to teach all special needs students $(E B D / M I D / L D)(\mathrm{N}=242 ; \mathrm{M}=2.68 ; \mathrm{SD}=$ $0.74)$, as the teachers agreed more with this affirmation. Once again, differences were observed between the teachers, as the regular teachers had a statistically less favorable response to the statement compared to their colleagues in special education.

The teachers generally disagreed with the affirmation EBD/MID/LD students fare better in regular classes than in individualized learning classes $(\mathrm{N}=227 ; \mathrm{M}=1.98 ; \mathrm{SD}=$ 0.70). However, again, differences were observed between teachers, as the special education teachers disagreed more with this statement than did their colleagues in the other two groups. These two last statements on individualized learning classes were correlated $(\mathrm{r}$ $=-.41 ; p<.001)$.

For the statement, "In the individualized learning classes, emphasis is placed on a student's difficulties rather than on his capacities." $(\mathrm{N}=230 ; \mathrm{M}=2.25 ; \mathrm{SD}=0.77)$, teachers are more in disagreement with this point. Also, no significant difference was observed between the three groups of teachers.

Finally, about the effects on these classes, on the item Being in an individualized learning class stigmatizes EBD/MID/LD students $(\mathrm{N}=$ 239), the teachers were more in disagreement $(\mathrm{M}=2.34 ; \mathrm{SD}=0.72)$. Differences were again observed between teachers, with a significantly greater positive response reported by the regular education teachers on this item. For the statement "Individualized learning classrooms demotivate students who attend them". ( $\mathrm{N}=235 ; \mathrm{M}=2.01 ; \mathrm{SD}=0.62)$, the teachers are also more in disagreement.

\section{Discussion}

Overall, a certain level of disagreement regarding the current reform on inclusive education was observed, although some positive effects on EBD/MID/LD students were highlighted. Indeed, Québec's reform received a less than lukewarm welcome on the part of teachers in this province. In addition, a consensus favored limiting the number of students with behavior or learning difficulties in the regular classroom, which ultimately translated to a greater use of special and individualized learning classes. The teachers in this study were doubtful that special needs students could in fact be included and were more in favor of special classes. These findings appear to be in agreement with those of Koutrouba, Vamvakari, and Steliou [12].

Regarding the effects of inclusive education, these are contradictory: there is a positive impact in terms of modeling the learners in the regular classroom, yet this setting may lead to a stigmatisation of EBD/MID/LD students. Overall, the teachers believed that the presence of students with specific needs may actually have a negative impact on the other learners in the regular classroom [12]. Results similar to those of Cardin, Falardeau and Bidjang with respect to workload are observed. According to the teachers, the presence of students with difficulties in regular classes requires them to increase their preparation time [7].

The teachers questioned were more divided on the impact of the Politique de l'adaptation scolaire than on the choice of private schools and selective programs, such as those of Cardin, Falardeau and Bidjang who observed that three-quarters of teachers questioned claim that the Politique de l'adaptation scolaire has drawn strong students toward the private school network or to the public school system's selective programs [7].

Studies show that special teachers are more optimistic toward students with behavior and/or learning difficulties but are less so toward their educational and social inclusion [10]. The regular education teachers in this study were less inclined to believe that these students will succeed in the regular classroom and were thus more in favor of special education classes. Furthermore, these students did not learn at the same pace as the others, thus signifying more work for the teachers involved.

While the teachers in the regular classrooms were also more inclined to think that too many resources are provided for services to EBD/MID/LD students, to the detriment of the other students, they did indicate a lack of resources for their students as a whole. Variables related to a lack of available material and human resources were associated with negative attitudes toward inclusion [4].

Generally, regular and specialized teachers have similar opinions about most of the issues. The most important differences concern classes for individualized learning representation, the success of EBD/MID/LD students, and the effects of inclusion.

\section{Conclusion}

Thirty of the 57 items on the questionnaire were considered in this study. The items more specifically concerning the policy's representations, resources, population, actions 
and effects, plus individualized learning classes, were analyzed. A subsequent study will analyze and present the results.

As well, results are strongly contextualized in Québec's situation. It would be interesting to compare the results with other inclusion policies in Canada (e.g., New Brunswick) to see if teachers' representations are more positive and thus research to find the reasons why.

To conclude, the study confirms that teachers' attitudes toward inclusive education have not been fully examined within the context of special education reforms in Québec. Further research must be conducted to broaden the understanding of the challenges of inclusive education for students with behavior disorder, mild intellectual disabilities or learning disabilities students (EBD/MID/LD) so as to equip schools to better address the issue.

\section{References}

[1] S. Bélanger, "Attitudes des différents acteurs scolaires à l'égard de l'inclusion", In N. Rousseau (dir.), La pédagogie de l'inclusion scolaire 2e éd, Les Presses de l'Université du Québec, Québec,

2010.

[2] Ministère de l'Éducation, du Loisir et du Sport. 'Les élèves handicapés ou en difficulté d'adaptation ou d'apprentissage : évolution des effectifs et cheminement scolaire à l'école publique'. Dépôt légal-Bibliothèque et Archives nationales du Québec 2009.

[3] Romano, K. and Chambliss, C, K-12 Teachers' and Administrators' Attitudes toward Inclusive Educational Practices, 2000. ERIC ED 443215

[4] E. Avramidis and B. Norwich, "Teachers' attitudes towards integration/inclusion: A review of the literature", European Journal of Special Needs Education, 2002, pp. 129-147.

[5] Ministère de l'Éducation du Québec, Politique de l'adaptation scolaire. Une école adaptée à tous ses élèves, Gouvernement du Québec, Québec, 1999.

[6] L. Gaudreau, F. Legault, M. Brodeur, M. Hurteau, A. Dunberry, L.P. Séguin and R. Legendre, Rapport d'évaluation de l'application de la Politique de l'adaptation scolaire. Ministère de l'Éducation, du Loisir et du Sport, Direction de l'adaptation scolaire, Montréal, Université du Québec à Montréal, 2008.

[7] J.-F. Cardin, É. Falardeau and S.-G. Bidjang, "Tout ça, pour ça... Le point de vue des enseignants $\mathrm{du}$ primaire et du secondaire sur la réforme des programmes au Québec », Formation et profession, 2012, 20(1), pp 9-22.

[8] J. Ellins and J. Porter, "Departmental differences in attitudes to special educational needs in the secondary school", British Journal of Special Education, 2005, pp. 188-195.

[9] A.K. Van Reusen, A.R. Shoho, and K.S. Barker, "High school teacher attitudes toward inclusion", The High School Journal, 2001, pp. 7-21.

[10] K. Brady and L. Woolfson, "What teacher factors influence their attributions for children's difficulties in learning", British Journal of Educational Psychology, 2008, pp. 527-544.

[11] D. K. Singh, "General education teachers and students with physical disabilities", The International Journal of Learning, 14(7), pp 205-210.

[12] K. Koutrouba, M. Vamvakari, and M. Steliou, "Factors correlated to teachers' attitudes towards the inclusion of students with special educational needs in Cyprus", European Journal of Special Needs Education, 2006, pp. 381-394.

[13] P. Tremblay, "L'évaluation de la qualité de dispositifs scolaires: développement d'une approche multidimensionnelle et bidirectionnelle", Mesure et évaluation en éducation, 2012, pp. 39-68.

[14] B. Bouchard and J. Plante, "La qualité: mieux la définir pour mieux la mesurer". Cahier du service de pédagogie expérimentale, 2002, 11-12, pp 219-236.

[15] A. Blais and C. Durand, "Le sondage", In B. Gauthier (dir.), Recherche sociale: de la problématique à la collecte des données. Les Presses de l'Université du Québec, Québec, 2009a.

[16] A. Blais and C. Durand, "La mesure", In B. Gauthier (dir.), Recherche sociale: de la problématique à la collecte des données, Les Presses de l'Université du Québec, Québec, 2009b. 